\title{
STUDIES ON THE LINOLEIC ACID CONTENTS IN THE PHOSPHOLIPIDS OF THE SARCOMA
}

\author{
YUJI SUEYOSHI* and YOSHIKAGE NAGAO \\ Department of Biochemistry, School of Medicine \\ Keio University, Tokyo
}

(Received for publication January 20, 1962)

According to the report of Haven(1), the iodine number of the fatty acids in the phospholipids of the tumor tissue is less than that of the normal muscle. Studying on this fact, Sueyoshi et al.(2) have found that this is due to the lesser amount of linoleic acid in the unsaturated fatty acid fractions of phospholipids of the tumor tissue.

It is the purpose of this paper to investigate the reason why there is only a small quantity of linoleic acid present in the tumor tissue.

\section{EXPERIMENTAL METHOD AND MATERIAL}

For experimental animals we have used albino rats of nonpure strain, weighing about $70 \mathrm{~g}$ and the diet having the following composition:

$\begin{array}{lr}\text { Starch } & 72 \% \\ \text { Casein } & 18 \% \\ \text { Inorganic Salts (McCollum) } & 4 \% \\ \text { Oryzanin Powder (Vitamin B complex) } & 4 \% \\ \text { Biosterin (Vitamin A, D) } & 5 \text { drops }\end{array}$

Tumor is obtained by transplantation of Fujinawa strain sarcoma to normal rats. By this method the tumor reaches its maximal growth by the end of the second week and the rats die uniformly in 1-2 days thereafter.

The tumor tissue for analysis is prepared as follows: At the end of the second week the tumor is extirpated and the central soft portion is discarded and materials from 5 animals are well mixed and analyzed as one experiment. As control, the normal muscle neighboring the tumor tissue is used. The analysis of the unsaturated fatty acids was carried out by the method described by Miura(3).

\footnotetext{
* Emeritus professor of Biochemistry.
} 


\section{Experiment $I$.}

\section{RESULTS}

The results of the analysis of the sarcoma and the muscles neighboring the sarcoma are shown in Table 1.

Table 1

Fatty acids contents of Fat and Phospholipid

in normal muscle and sacroma tissue

(The data are the average of 5 experiments)

\begin{tabular}{|c|c|c|c|c|}
\hline & \multicolumn{2}{|c|}{ Muscle } & \multicolumn{2}{|c|}{ Sarcoma } \\
\hline & $\begin{array}{c}\text { Fat } \\
\% 0\end{array}$ & $\begin{array}{c}\text { Phospholipid } \\
\%\end{array}$ & $\begin{array}{c}\text { Fat } \\
\mathscr{O}\end{array}$ & Phospholipid \\
\hline Total fatty acid & 1.08 & 0.88 & 0.46 & 1.19 \\
\hline Unsaturat. fatty acid & 0.82 & 0.57 & 0.34 & 0.79 \\
\hline \multicolumn{5}{|c|}{ In unsaturated fatty acid } \\
\hline Oleic acid & 96.23 & 59.05 & 83.45 & 82.82 \\
\hline Linoleic acid & 2.51 & 28.83 & 11.61 & 10.96 \\
\hline Linolenic acid & 0.88 & 5.89 & 3.23 & 3.05 \\
\hline Arachidonic acid & 0.38 & 6.23 & 1.71 & 3.17 \\
\hline
\end{tabular}

According to the results in Table 1, the most apparent difference between the fatty acid contents of normal muscle and of the tumor is the amount of linoleic acid of phospholipids. In the normal muscle, the amount of linoleic acid is $28.83 \%$, whereas the amount of linoleic acid in the sarcoma is only $10.96 \%$. The results agree well with the previous report of Sueyoshi et al(2). Experiment II.

As aforementioned, the amount of linoleic acid of phospholipids of the tumor is much less than that of phospholipids of the normal muscle, and this we though to be due probably to the following reasons:

(a) There is difficulty in incorporation of linoleic acid into the phospholipids of the tumor from the diet supplied;

(b) Or, even if the linoleic acid of diet is normally incorporated into the phospholipids of the tumor, it might be rapidly consumed.

In order to investigate which of the above two points will be correct, the authors carried out the following experiments:

(A) Sarcoma is transplanted to the rats and after the growth of the tumor is ascertained at the end of the first week, linseed oil, which contains linoleic acid abundantly, is added to the food in $25 \%$ amount and fed to the rats for 2 days, 4 days and 7 days thereafter, and the tissue of each group of rats is analyzed. The results of the analysis are shown in Table 2. 
Table 2

Fatty acids contents of Fat and Phospholipid in normal muscle and sarcoma tissue on linseed oil diet

(The data are the average of 5 experiments)

\begin{tabular}{|c|c|c|c|c|}
\hline & \multicolumn{4}{|c|}{ (A) 2 days on linseed oil diet } \\
\hline & \multicolumn{2}{|c|}{ Muscle } & \multicolumn{2}{|c|}{ Sarcome } \\
\hline & $\begin{array}{c}\text { Fat } \\
\% 6\end{array}$ & $\begin{array}{c}\text { Phospholipid } \\
\%\end{array}$ & Fat & Phospholipid \\
\hline Total fatty acid (T) & 0.93 & 0.91 & 0.33 & 1.11 \\
\hline Unsaturat. fatty acid (U) & 0.71 & 0.71 & 0.26 & 0.75 \\
\hline $\mathrm{U}: \mathrm{T}$ & 76.8 & 77.0 & 77.9 & 67.3 \\
\hline \multicolumn{5}{|c|}{ In unsaturated fatty acid } \\
\hline Oleic acid & 95.72 & 64.95 & 85.32 & 79.77 \\
\hline Linoleic acid & 3.55 & 29.46 & 11.43 & 13.82 \\
\hline Linolenic acid & 0.56 & 2.50 & 2.54 & 3.72 \\
\hline Arachidonic acid & 0.17 & 3.09 & 0.71 & 2.69 \\
\hline
\end{tabular}

\begin{tabular}{|c|c|c|c|c|}
\hline & \multicolumn{4}{|c|}{ (B) 4 days on linseed oil diet } \\
\hline & \multicolumn{2}{|c|}{ Muscle } & \multicolumn{2}{|c|}{ Sarcoma } \\
\hline & $\begin{array}{l}\text { Fat } \\
\%\end{array}$ & $\begin{array}{c}\text { Phospholipid } \\
\%\end{array}$ & $\begin{array}{c}\text { Fat } \\
\%\end{array}$ & Phospholipid \\
\hline Total fatty acid $(\mathrm{T})$ & 1.32 & 0.94 & 0.23 & 1.16 \\
\hline Unsaturat. fatty acid (U) & 1.00 & 0.66 & 0.19 & 0.84 \\
\hline $\mathrm{U}: \mathrm{T}$ & 75.8 & 70.3 & 80.9 & 73.1 \\
\hline
\end{tabular}

In unsaturated fatty acid

\begin{tabular}{|c|c|c|c|c|}
\hline Oleic acid & 91.71 & 48.39 & 80.00 & 73.77 \\
\hline Linoleic acid & 6.75 & 38.58 & 15.90 & 21.16 \\
\hline Linolenic acid & 1.38 & 6.11 & 3.17 & 3.05 \\
\hline Arachidonic acid & 0.16 & 6.92 & 0.93 & 2.02 \\
\hline
\end{tabular}

\begin{tabular}{|c|c|c|c|c|}
\hline & \multicolumn{4}{|c|}{ (C) 7 days on linseed oil diet } \\
\hline & \multicolumn{2}{|c|}{ Muscle } & \multicolumn{2}{|c|}{ Sarcoma } \\
\hline & $\begin{array}{c}\text { Fat } \\
90\end{array}$ & Phospholipid & $\begin{array}{c}\text { Fat } \\
96\end{array}$ & $\underset{9_{0}}{\text { Phospholipid }}$ \\
\hline Total fatty acid $(T)$ & 1.07 & 0.86 & 0.60 & 1.23 \\
\hline Unsaturat. fatty acid (U) & 0.82 & 0.57 & 0.45 & 0.76 \\
\hline $\mathrm{U}: \mathrm{T}$ & 76.7 & 66.9 & 75.9 & 61.5 \\
\hline
\end{tabular}

In unsaturated fatty acid 


\begin{tabular}{l|rr|rr}
\hline Oleic acid & 87.47 & 52.38 & 80.84 & 67.51 \\
Linoleic acid & 9.38 & 34.43 & 14.63 & 23.64 \\
Linolenic acid & 2.65 & 6.99 & 3.09 & 4.60 \\
Arachidonic acid & 0.50 & 6.25 & 1.44 & 4.25 \\
\hline
\end{tabular}

Table 3 is a summary of Table 1 and Table 2, which are the results of the analysis of unsaturated fatty acid of the phospholipids of the normal muscle and of the sarcoma tissue of the rats on normal diet and linseed oil diet, respectively. It is apparent from this Table that the materials from the animals fed on linseed oil diet all contain increased linoleic acid in the unsaturated fatty acid of the phospholipids. The animals given the linseed oil for 2 days show only a small increase of linoleic acid, whereas the animals which received linseed oil for 4 days or 7 days have remarkable increase of linoleic acid. In the group of animals which received linseed oil for 7 days, the rate of increase of linoleic acid content is $5.63 \%$ and $12.68 \%$ in normal muscle and sarcoma tissue, respectively.

Table 3

Comparison of linoleic acid contents in the Table 1 and 2

\begin{tabular}{c|cc|c|c|cc|c}
\hline \hline \multicolumn{3}{c|}{ Muscle } & \multicolumn{4}{|c|}{ Sarcoma } \\
\hline $\begin{array}{c}\text { Normal diet } \\
\%\end{array}$ & $\begin{array}{c}\text { Linseed oil diet } \\
\text { Days }\end{array}$ & $\begin{array}{c}\text { Differ. } \\
\%\end{array}$ & $\begin{array}{c}\text { Normal diet } \\
\%\end{array}$ & $\begin{array}{c}\text { Linseed oil diet } \\
\text { Days }\end{array}$ & $\begin{array}{c}\text { Differ. } \\
\%\end{array}$ \\
\hline 28.83 & 2 & 29.46 & 0.63 & 10.96 & 2 & 13.82 & 2.86 \\
$" \prime$ & 4 & 38.58 & 9.75 & $\prime \prime$ & 4 & 21.16 & 10.20 \\
$" \prime$ & 7 & 34.43 & 5.63 & $\prime \prime$ & 7 & 23.64 & 12.68 \\
\hline
\end{tabular}

(B) As shown above, when the sarcoma is transplanted to a rat and the rat is fed on a diet containing linseed oil, more linoleic acid will be incorporated in the phospholipid. In order to see how soon the linoleic acid which is incorporated into the phospholipids of the tissue by adding linseed oil to the diet will disappear from the tissue when the supply of linoleic acid is stopped, the author carried out the following experiment:

The linseed oil diet is fed to the rats, which have received sarcoma transplantation, for 7 days and then these rats are placed on a fat-free diet for 1 day (Group A), 2 days (Group B), 3 days (Group C) and 7 days (Group D) and the tissues of these rats are analyzed. The results are given in Table 4. The fat-free diet used in this experiment consists of Starch and Casein, from which fat has been extracted by the use of alcohol. Also, Oryzanin powder was extracted with ether, and unsaponifiable substances which were isolated from cod-liver oil were used instead of biosterin. Comparative results of the linoleic 
acid contents in the phospholipids of the normal muscle and sarcoma tissue of the fat-free diet group and the linseed-oil diet group are shown in Table 5.

Table 4

Fatty acids contents of Fat and Phospholipid in normal muscle and sarcoma tissue on fat-free diet

(The data are the average of 5 experiments)

\begin{tabular}{|c|c|c|c|c|}
\hline & \multicolumn{4}{|c|}{ (A) 1 day on fat-free diet } \\
\hline & \multicolumn{2}{|c|}{ Muscle } & \multicolumn{2}{|c|}{ Sarcoma } \\
\hline & $\begin{array}{c}\text { Fat } \\
\%\end{array}$ & $\begin{array}{c}\text { Phospholipid } \\
\%\end{array}$ & $\begin{array}{l}\text { Fat } \\
\%\end{array}$ & $\begin{array}{c}\text { Phospholipid } \\
\%\end{array}$ \\
\hline Total fatty acid (T) & 0.48 & 0.83 & 0.26 & 1.13 \\
\hline Unsaturat. fatty acid (U) & 0.38 & 0.56 & 0.20 & 0.73 \\
\hline $\mathrm{U}: \mathrm{T}$ & 78.2 & 66.9 & 71.0 & 64.8 \\
\hline \multicolumn{5}{|c|}{ In unsaturated fatty acid } \\
\hline Oleic acid & 90.74 & 54.81 & 82.89 & 76.55 \\
\hline Linoleic acid & 7.43 & 34.76 & 12.46 & 15.49 \\
\hline Linolenic acid & 1.44 & 5.81 & 2.69 & 3.60 \\
\hline \multirow[t]{4}{*}{ Arachidonic acid } & 0.39 & 4.62 & 1.96 & 4.36 \\
\hline & \multicolumn{4}{|c|}{ (B) 2 days on fat-free diet } \\
\hline & \multicolumn{2}{|c|}{ Muscle } & \multicolumn{2}{|c|}{ Sarcoma } \\
\hline & $\begin{array}{l}\text { Fat } \\
\%\end{array}$ & $\begin{array}{c}\text { Phospholipid } \\
\%\end{array}$ & $\begin{array}{c}\text { Fat } \\
96\end{array}$ & Phospholipid \\
\hline Total fatty acid $(T)$ & 0.39 & 0.81 & 0.21 & 1.11 \\
\hline Unsaturat. fatty acid (U) & 0.31 & 0.57 & 0.16 & 0.81 \\
\hline $\mathrm{U}: \mathrm{T}$ & 77.8 & 70.3 & 75.5 & 71.5 \\
\hline \multicolumn{5}{|c|}{ In unsaturated fatty acid } \\
\hline Oleic acid & 91.72 & 51.97 & 79.61 & 79.31 \\
\hline Linoleic acid & 6.66 & 36.70 & 14.95 & 13.58 \\
\hline Linolenic acid & 1.12 & 6.12 & 3.86 & 3.73 \\
\hline \multirow[t]{4}{*}{ Arachidonic acid } & 0.50 & 5.21 & 1.58 & 3.38 \\
\hline & \multicolumn{4}{|c|}{ (C) 3 days on fat-free diet } \\
\hline & \multicolumn{2}{|c|}{ Muscle } & \multicolumn{2}{|c|}{ Sarcoma } \\
\hline & $\begin{array}{c}\text { Fat } \\
\% \\
\end{array}$ & $\begin{array}{c}\text { Phospholipid } \\
\%\end{array}$ & $\begin{array}{c}\text { Fat } \\
\%\end{array}$ & $\begin{array}{c}\text { Phospholipid } \\
\%\end{array}$ \\
\hline Total fatty acid $(\mathrm{T})$ & 0.79 & 0.78 & 0.32 & 1.00 \\
\hline Unsaturat. fatty acid (U) & 0.57 & 0.53 & 0.26 & 0.69 \\
\hline $\mathrm{U}: \mathrm{T}$ & 71.3 & 65.1 & 82.8 & 68.6 \\
\hline
\end{tabular}


In unsaturated fatty acid

\begin{tabular}{l|rr|rr}
\hline Oleic acid & 87.15 & 47.71 & 78.63 & 81.01 \\
Linoleic acid & 10.57 & 37.31 & 15.85 & 12.74 \\
Linolenic acid & 2.04 & 7.71 & 3.43 & 2.95 \\
Arachidonic acid & 0.24 & 7.27 & 2.09 & 3.30 \\
\hline
\end{tabular}

\begin{tabular}{l|cc|cc}
\hline & \multicolumn{4}{|c}{ (D) 7 days on fat-free diet } \\
\cline { 2 - 5 } & \multicolumn{3}{|c|}{ Muscle } & \multicolumn{2}{c}{ Sarcoma } \\
& Fat & Phospholipid & Fat & Phospholipid \\
& $\%$ & $\%$ & $\%$ & $\%$ \\
\hline Total fatty acid (T) & 0.42 & 0.64 & 0.21 & 1.01 \\
Unsaturat. fatty acid (U) & 0.33 & 0.45 & 0.16 & 0.72 \\
$\mathrm{U}: T$ & 79.1 & 70.7 & 79.0 & 70.9 \\
\hline & In unsaturtaed fatty acid & & \\
\hline Oleic acid & 96.52 & 56.01 & 84.13 & 84.69 \\
Linoleic acid & 2.38 & 29.93 & 10.51 & 9.17 \\
Linolenic acid & 0.71 & 7.48 & 3.92 & $3.5 S$ \\
Arachidonic acid & 0.39 & 6.58 & 1.44 & 2.55 \\
\hline
\end{tabular}

Table 5

Comparison of linoleic acid contents of Phospholipid of Muscle and Sarcoma on linseed oil, and fat-free diets

\begin{tabular}{|c|c|c|c|c|c|c|c|}
\hline \multicolumn{4}{|c|}{ Muscle } & \multicolumn{4}{|c|}{ Sarcoma } \\
\hline $\begin{array}{c}\text { Linseed oil diet } \\
(7 \text { days }) \\
0_{0}\end{array}$ & $\begin{array}{l}\text { Fat-free d } \\
\text { Days }\end{array}$ & & $\begin{array}{c}\text { Differ. } \\
0 \%\end{array}$ & $\begin{array}{c}\text { Linseed oil diet } \\
(7 \text { days }) \\
0\end{array}$ & $\begin{array}{c}\text { Fat-fre } \\
\text { Days }\end{array}$ & $\begin{array}{l}\text { diet } \\
\% \%\end{array}$ & $\begin{array}{c}\text { Differ. } \\
\%\end{array}$ \\
\hline 34.43 & 1 & 4.76 & +0.33 & 23.64 & 1 & 15.49 & -8.15 \\
\hline " & 2 & 6.70 & +2.27 & $"$ & 2 & 13.58 & -10.06 \\
\hline$" 1$ & 3 & 7.31 & +2.88 & $"$ & 3 & 12.74 & -10.90 \\
\hline " & 7 & 9.93 & -450 & " & 7 & 9.17 & -14.47 \\
\hline
\end{tabular}

According to Table 5, the linoleic acid of phospholipids of normal muscles of rats on the fat-free diet does not decrease on the 1st day, 2nd day or the 3rd day. Only on the 7 th day is the decrease of $4.50 \%$ noted. However, the linoleic acid of phospholipids of tumor tissue of sarcoma rats on the fat-free diet, even on the first day, shows a decrease of $8.15 \%$ and the total amount of linoleic acid is $15.49 \%$. When the rats are placed on the fat-free diet for 2 days, the results show a decrease to $13.58 \%$, and for 3 days, a decrease to $12.74 \%$, and on the 7 th day it decreases to $9.17 \%$, which approaches that of the rat on a normal diet. 
According to the above results, the disappearance of linoleic acid of the phospholipids of tumor tissue is very rapid compared with the normal muscles.

\section{SUMMARY}

In order to find the reason why there is only a small amount of linoleic acid in the unsaturated fatty acids fraction of phospholipids in the tumor tissue, the authors have made studies about this point on the transplanted sarcoma and neighboring normal muscle tissues of the rats.

1) The amounts of total unsaturated fatty acid in the phospholipids of the tumor and that of the normal muscles are almost equal.

2) The amounts of linoleic acid and linolenic acid of phospholipids of the tumor are of very small quantity compared with the amounts of that of the phospholipids of the normal muscles. Especially, the amount of linoleic acid is of remarkably small quantity.

3) The mechanism under which the above phenomena appear can be thought of as follows:

(a) The linoleic acid in the diet might be very difficult to be incorporated into the phospholipids of the tumor, or

(b) The linoleic acid of phospholipids of the tumor might disappear at a more rapid rate than that of normal muscles.

Investigating on these two factors, the authors obtained the following results :

(A) When linseed oil is added to the diet and fed to the rats for 7 days, increase of the linoleic acid portion of unsaturated fatty acid of phospholipids of normal muscle is $5.44 \%$, whereas that of tumor tissue is $13.83 \%$.

According to this result, the rate of incorporation of linoleic acid from the diet into the phospholipids is more rapid in the tumor tissue than in the normal muscles. The same result is obtained when the linseed oil diet is given for 4 days.

(B) After the linseed oil diet is given for 7 days, then the fat-free diet is given from 1-7 days, and the tissues of these animals are analyzed. Results show that the linoleic acid of phospholipids of the normal muscles is not decreased even after 3 days and only a slight amount of decrease is noted after 7 days. However, on the fat-free diet, even after 1 day, the linoleic acid of phospholipids of the tumor shows some decrease, and on the 2 nd and 3rd days the decrease is remarkable. According to this result, the disappearance of linoleic acid in the phospholipids is more rapid in the tumor than in the normal muscles. 
4) According to the above results, the amount of the linoleic acid in the phospholipids of the tumor is less than that in phospholipids of the normal muscles, not because of difficulty of incorporation of linoleic acid from the diet into the phospholipids of the tumor, but due to its rapid disappearance from the tumor tissue.

\section{REFERENCES}

1. Haven, F. L.: J. biolog. chem. 118: 111, 1937.

2. Sueyoshi, Y. and Miura, K.: J. biochem. 29: 481, 1939.

3. Miura, K.: J. biochem. 29: 467, 1939. 